\title{
EFISIENSI PEMASARAN TERUNG UNGU (Solanum melongena L.) DI KABUPATEN INDRAMAYU
}

\author{
Mochammad Putra Jagad Samudra' ${ }^{1}$, Juri Juswadi², Fadhillah Laila ${ }^{3}$ \\ 1,2,3 Program Studi Agribisnis, Fakultas Pertanian, Universitas Wiralodra

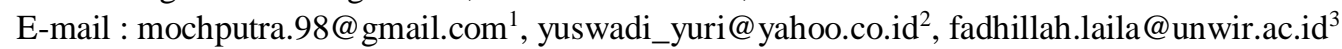

\begin{abstract}
ABSTRAK
Penelitian ini bertujuan untuk mengetahui (1) Nilai elastisitas transmisi harga terung ungu di Kabupaten Indramayu; (2) Efisiensi pemasaran terung ungu di Kabupaten Indramayu. Metode yang digunakan dalam penelitian ini adalah metode subject matter research dan menggunakan desain deskriptif. Penelitian ini menggunakan model ekonometrika dengan data time-series harga bulanan produsen dan konsumen dari bulan Januari 2013 sampai Desember tahun 2017. Hasil penelitian ini menunjukkan bahwa nilai elastisitas transmisi harga sebesar 0,970. Et kurang dari 1 yang berarti perubahan harga sebesar $1 \%$ di tingkat konsumen akan mengakibatkan perubahan harga di tingkat produsen sebesar $0,970 \%$. Nilai elastisitas transmisi harga terung ungu tidak sama dengan 1 (satu). Maka pemasaran terung ungu di Kabupaten Indramayu dikatakan tidak efisien, karena nilai Et kurang dari 1 dan keadaan pasar tidak mencerminkan pasar persaingan sempurna.
\end{abstract}

Kata Kunci : Terung Ungu, Efisiensi, Pemasaran, Pasar, Elastisitas.

\section{I.PENDAHULUAN}

Pertanian merupakan sektor penting dalam perekonomian Indonesia. Peran pertanian sangat penting terutama untuk menggerakan sektor ekonomi, baik dalam mewujudkan ketahanan pangan, turut serta mendukung perkembangan pada sektor sekunder dan tersier, serta memberikan kontribusi peningkatan penerimaan devisa Negara (Kartasapoetra,1987). Indonesia sebagai negara agraris yang memiliki sumber daya alam melimpah menjadi potensi untuk kemajuan ekonomi Indonesia. Potensi subsektor pertanian di Indonesia salah satunya adalah bidang hortikultura. Hortikultura yaitu ilmu yang ditunjang dari beberapa ilmu seperti agronomi, pemuliaan tanaman, proteksi tanaman dan teknologi benih. Hortikultura terbagi menjadi tiga golongan yakni tanaman buahbuahan, tanaman sayuran, tanaman bunga dan tanaman obat. Tanaman hortikultura ini terpisah dari jenis tanaman perkebunan, tanaman pangan dan tanaman yang lain. Hal ini disebabkan hortikultura berfungsi dan bersifat lain (Arief dalam Widyaningsih, 2018). Salah satu tanaman hortikultura yang banyak dibudidayakan adalah tanaman terung khususnya terung ungu.

Terung ungu adalah jenis sayuran yang dapat dijadikan lalapan, memiliki rasa yang enak dan sangat popular di masyarakat. Selain itu terung ungu juga mengandung gizi yang cukup tinggi, terutama kandungan vitamin A dan Fosfor. Komoditas terung ungu cukup potensial untuk dikembangkan untuk diversifikasi (keanekaragaman) bahan sayuran bergizi bagi penduduk. Kabupaten Indramayu adalah salah satu wilayah agraris yang memiliki potensi untuk mengembangkan tanaman hortikultura, guna menunjang pemenuhan kandungan gizi dan pembangunan perekonomian daerah.

Kondisi alam di Kabupaten Indramayu sangat mendukung untuk dikembangkan budidaya hortikultura termasuk tanaman terung. Sehingga optimalisasi hasil produksi dari tanaman terung dapat tercapai. Wilayah dengan produksi terung tertinggi di Kabupaten Indramayu yaitu meliputi Kecamatan Sliyeg, Kecamatan Indramayu, dan Kecamatan Terisi. Tempat terbesar pemasaran terung ungu di 
Kabupaten Indramayu ada 2, yaitu pasar Jatibarang yang terletak di Kecamatan Jatibarang dan pasar Patrol yang berada di Kecamatan Patrol. Harga jual Terung Ungu di Kabupaten Indramayu Tahun 2017 berkisar antara Rp 4.000 - Rp 7.000/kg. Harga terung ungu di beberapa wilayah Kabupaten Indramayu dipengaruhi oleh beberapa faktor, diantaranya jumlah produk dan rantai pemasaran. Salah satu indicator dari Integrasi atau keterpaduan pasar adalah efisiensi harga. Keterpaduan pasar sendiri merupakan hubungan antara harga dua pasar atau lebih. Dua pasar dikatakan terpadu atau terintegrasi apabila perubahan harga dari salah satu pasar disalurkan kepasar lainnya. Struktur dan integrasi pasar berkaitan dengan pembentukan harga dan efisien pemasaran. Analisis struktur dan integrasi pasar dapat menggambarkan efektivitas dan tingkah laku pasar ditingkat produsen dan konsumen, pada masingmasing tingkat mempunyai kekuatan permintaan dan penawaran (Rahayuningsih, 2009).

Efisiensi pemasaran merupakan penilaian mengenai indikasi kesejahteraan bagi pelaku kegiatan produksi pertanian meliputi produsen, lembaga pemasaran, dan konsumen. Kesejahteraan petani pun terhambat karena rendahnya posisi tawar ditingkat petani dapat mengakibatkan petani lemah dalam permodalan dari pelaku pemasaran. Kurangnya informasi pasar di kalangan petani mengakibatkan harga yang diterima oleh petani rendah karena farmer's share atau bagian harga yang diperoleh oleh petani rendah dan asimetris informasi (Andriani, 2015). Berdasarakan pertimbangan dari bagian permasalahan diatas. Penulis tertarik untuk meneliti dengan judul "Analisis Efesiensi Pemasaran Terung (Solanum melongena L.) di Kabupaten Indramayu Periode 2013 - 2017”

\section{Tujuan Penelitian}

Penelitian ini bertujun untuk mengetahui nilai elastisitas trasmisi pada harga terung ungu di Kabupaten Indramayu dan mengetahui efesiensi pemasaran terung ungu di Kabupaten Indramayu.

\section{II.METODE PENELITIAN}

\section{Lokasi dan Waktu Penelitian}

Penelitian ini dilakukan pada bulan November 2018 sampai dengan bulan Agustus 2019 di Kabupaten Indramayu Provinsi Jawa Barat dan dipilih secara sengaja (purposive).

\section{Metode Pengumpulan Data}

Metode penelitian ini adalah komperatif merupakan sejenis peneltian deskriptif yang ingin mengetahui tentang sebab-akibat dengan menganalisis faktor-faktor penyebab terjadinya fenomena tertentu (Nazir, 2011). Sedangkan desain dalam penelitian ini adalah kausal komparatif (causal comparative research) dengan menggunakan data time-series harga bulanan produsen dan konsumen dari bulan Januari 2013 sampai dengan bulan Desember tahun 2017. Jenis penelitian ini adalah data kuantitatif dengan menggunakan data sekunder yang bersumber pada data bulanan harga terung ungu bulan Januari tahun 2013 sampai dengan bulan Desember tahun 2017 yang berasal dari Badan Pusat Statistika Kabupaten Indramayu. Data diperoleh dari hasil studi pustaka.

\footnotetext{
Analisis Data berdasarkan Gujarati (2012) dengan rumus sebagai berikut:

$\mathrm{P} f=\beta 0+\operatorname{Pr} \beta 1 \mathrm{e}$

Kemudian ditransformasikan dalam bentuk linier menjadi:

$\operatorname{LnPf}=\operatorname{Ln} \beta 0+\beta 1 \operatorname{LnPr}+\mathrm{e}$

Keterangan:

$\beta 0$ : Intersep

$\beta 1:$ Koefesien elastisitas

$\operatorname{Pr}$ : Harga rata-rata bulanan ditingkat konsumen $(\mathrm{Rp})$
}

Menganalisis efisiensi pemasaran terung ungu dalam penelitian ini menggunakan analisis transmisi harga 
Pf : Harga rata-rata bulanan ditingkat produsen (petani) (Rp)

e : Gangguan stokhastik atas kesalahan (disturbance term) Untuk mempermudah perhitungan maka digunakan rumus sebagai berikut:

$\operatorname{LnPf}=\operatorname{Ln} \beta 0+\beta 1 \mathrm{LnHK}+\mathrm{e}$

Keterangan:

$\beta 0$ : Intersep

$\beta 1:$ Koefesien elastisitas

HK : Harga rata-rata bulanan ditingkat konsumen $(\mathrm{Rp})$

$\mathrm{HP}$ : Harga rata-rata bulanan ditingkat produsen (petani) (Rp)

e : Gangguan stokhastik atas kesalahan (disturbance term)

\section{III.HASIL DAN PEMBAHASAN}

\section{Elastisitas Transmisi Harga}

Elastisitas transmisi harga merupakan perbandingan harga di tingkat pengecer dengan perubahan harga di tingkat petani (Sudiyono, 2000). Elastisitas transmisi harga merupakan perbandingan perubahan persentase dari harga ditingkat konsumen dengan perubahan harga ditingkat produsen, yang bertujuan untuk mengetahui melihat berapa besar perubahan harga di pasar konsumen akibat terjadinya perubahan harga sebesar satu satuan unit di pasar produsen. Dari perubahan/hubungan tersebut secara tidak langsung dapat diperkirakan tingkat keefektifan suatu informasi pasar, bentuk pasar dan efektivitas sistem pemasaran. Elastisitas transmisi harga kurang dari satu $(\mathrm{Et}<1)$ artinya perubahan harga $1 \%$ di tingkat konsumen akan mengakibatkan perubahan harga yang $<1 \%$ di tingkat produsen. (Et $=1$ ), berarti perubahan harga $1 \%$ di tingkat konsumen mengakibatkan perubahan $1 \%$ di tingkat produsen, sedangkan (Et $>1$ ), berarti perubahan harga 1\% di tingkat konsumen mengakibatkan $>1 \%$ di tingkat produsen. Algifari (2000) menyatakan bahwa bentuk umum dari persamaan linier sederhana yang menunjukkan hubungan antara dua variabel, yaitu variabel $X$ sebagai variabel independen dan $Y$ sebagai variabel dependen adalah $\mathrm{Y}=\mathrm{a}+\mathrm{bX}$ yang menunjukkan bahwa: $\mathrm{Y}$ adalah variabel dependen a adalah intersep (titik potong kurva terhadap sumbu $\mathrm{Y}$ ) b adalah kemiringan (slaape) kurva linier $\mathrm{X}$ adalah variabel independen variabel $\mathrm{Y}$ adalah harga di tingkat produsen dan variabel $\mathrm{X}$ adalah harga di tingkatkan konsumen. Nilai $b$ adalah kemiringan (slope) kurva linier yang menunjukkan besarnya perubahan nilai $\mathrm{Y}$ sebagai akibat dari perubahan setiap unit X. besarnya $a$ dan $b$ konstan sepanjang kurva linier. Model ekonometrika menurut Gujarati (2012) menggunakan regresi kuadratik dengan persamaan sebagai berikut:

$\mathrm{P} f=\beta 0+\operatorname{Pr} \beta 1 \mathrm{e}$

Kemudian ditransformasikan dalam bentuk linier menjadi:

$\mathrm{LnPf}=\mathrm{Ln} \beta 0+\beta 1 \mathrm{LnPr}+\mathrm{e}$

$\operatorname{LnPf}=-0,150+0,970 \operatorname{LnPr}+\mathrm{e}$

Persamaan di atas menunjukkan bahwa nilai Et sebesar 0,970. Nilai tersebut menunjukkan bahwa Et $<1$, artinya perubahan harga terung ungu sebesar $1 \%$ menunjukkan persentase kenaikan harga di tingkat konsumen lebih rendah dibandingkan tingkat produsen dan perubahan harga sebesar 1\% di tingkat konsumen akan mengakibatkan perubahan harga di tingkat produsen sebesar $0,970 \%$. Nilai konstanta $(b 0)$ artinya setiap nilai konstanta yang dihasilkan baik nilai konstanta negatif (-) maupun (+) akan selalu mempengaruhi harga di tingkat produsen maupun konsumen. Jika nilai konstanta negatif (-) artinya harga di tingkat produsen berada di bawah nol karena tidak ada permintaan dari konsumen atau bagian harga yang diterima produsen rendah karena nilai konstanta bernilai (-). Besarnya nilai koefisien determinasi (R2) yaitu 0,970 artinya, nilai koefisien determinasi (R2) semakin mendekati satu besarnya koefisien determinasi (R2) suatu persamaan regresi, semakin besar pula pengaruh variabel independen terhadap variabel dependen (dengan kata lain semakin besar kemampuan model yang dihasilkan dalam menjelaskan perubahan nisbi variabel dependen). 


\section{Uji Asumsi Klasik}

\section{Normalitas Data}

Uji Normalitas mempunyai tujuan untuk menguji apakah dalam model regresi variabel pengganggu atau residual memiliki distribusi normal atau tidak. Apabila data terdistribusi normal maka data memusat pada nilai rata-rata dan median. Secara sederhana untuk mengetahui distribusi data dapat dilakukan dengan menggunakan grafik distribusi dan statistik. Menggunakan grafik distribusi dalam upaya untuk mengetahui normalitas data adalah dengan cara yang paling mudah dan sederhana (Gujarati, 2012). Hasil output SPSS 23 pada gambar 4. menunjukkan bahwa pola titik yang tersebar mengikuti garis diagonal maka disimpulkan bahwa data berdistribusi normal.

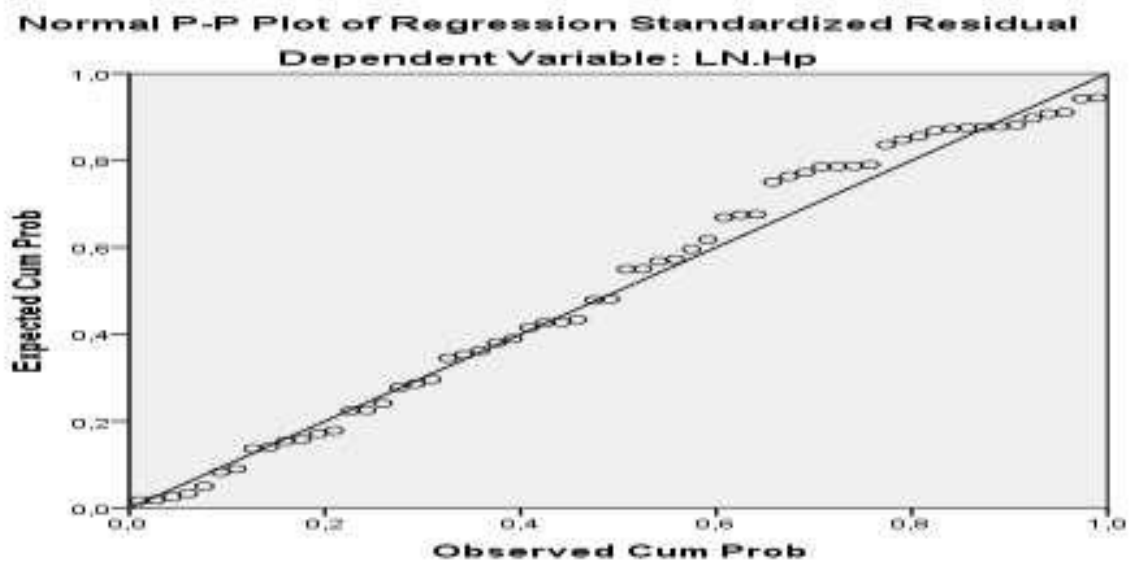

Gambar 4. Normal P-Plot of Regression Standard Residual

\section{Multikolinieritas}

Uji multikolinieritas bertujuan untuk menguji apakah ada korelasi antara model regresi dengan variabel bebas. Model regresi yang baik yaitu tidak ada korelasi diantara variabel independen (Denziana, 2014).

Hasil output SPSS 23 pada Tabel 6. Nilai VIF sebesar 1 dan nilai tolerance sebesar 1 yang menunjukkan bahwa tidak terdapat multikolinieritas pada data tersebut.

\section{Coefficients $^{a}$}

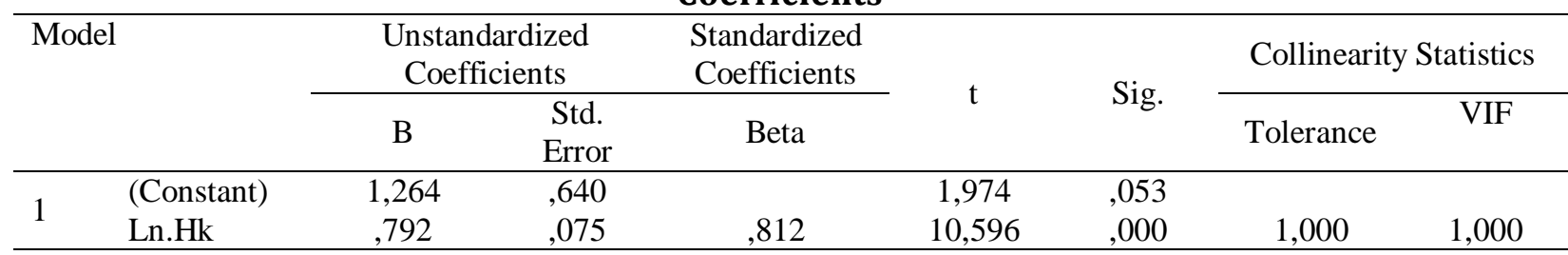

a. Dependent Variable: LN.Hp

Tabel 6. Nilai Koefisien Regresi dan Nilai VIF Ln Harga Produsen dan Konsumen Terung Ungudi Kabupaten Indramayu Tahun 2013-2017

\section{Autokorelasi}

Uji autokorelasi adalah sebuah alat analisis statistik untuk mengetahui adakah korelasi variabel di dalam model prediksi dengan perubahan waktu. Apabila terjadi aoutokorelasi pada model prediksi, maka nilai disturbance tidak lagi berpasangan secara bebas, melainkan berpasangan secara autokorelasi. Uji autokorelasi dilakukan untuk data time series atau runtut waktu. Sebab yang dimaksud dengan autokorelasi sebenarnya yaitu nilai sempel tertentu yang dipengaruhi oleh nilai observasi sebelumnya (Hidayat, 2017). Asumsi pada regresi dimana variabel dependen tidak autokorelasi dengan menggunakan 
uji Durbin-Watson (DW). Uji ini menghasilkan nilai DW hitung (d) dan nilai DW table (dl \& du). Hasil dari analisis regresi Tabel 7. Nilai DW hitung $(d)$ sebesar 1,155 lebih kecil dari nilai $d l=1,514$ dan $d u=$ 1,652 yaitu menunjukkan adanya autokorelasi positif (terjadi autokorelasi). Data time series sering terjadi autokorelasi (Mubyarto, 1989), menggunakan bahwa terjadinya jarak waktu yang lebar antara pengeluaran dan penerimaan dalam pertanian. Perbedaan yang jelas antara personal-personal ekonomi pertanian dan personal di luar bidang pengusaha pertanian antara jarak waktu pengeluaran perlu dilakukan pada pengusaha pertanian dengan pendapatan hasil penjualan. Jarak waktu sering disebut gestation period.

Tabel 7. Nilai Koefisien Regresi Harga Produsen dan Konsumen Terung Ungu di Kabupaten Indramayu Tahun 2013-2017.

\begin{tabular}{|c|c|c|c|c|c|c|c|c|}
\hline \multicolumn{9}{|c|}{ Model Summary ${ }^{b}$} \\
\hline \multirow[t]{2}{*}{ Model } & \multirow[t]{2}{*}{$\mathrm{R}$} & \multirow{2}{*}{$\begin{array}{c}\mathrm{R} \\
\text { Square }\end{array}$} & \multirow{2}{*}{$\begin{array}{l}\text { Std. Error of } \\
\text { the } \\
\text { Estimate }\end{array}$} & \multicolumn{4}{|c|}{ Change Statistics } & \multirow[t]{2}{*}{ Durbin-Watson } \\
\hline & & & & $\begin{array}{c}\mathrm{R} \\
\text { Square } \\
\text { Change } \\
\end{array}$ & $\begin{array}{c}\mathrm{F} \\
\text { Change }\end{array}$ & df1 df2 & $\begin{array}{l}\text { Sig. F } \\
\text { Change }\end{array}$ & \\
\hline 1 &, $812 \mathrm{a}$ & 659 & 10977924173 & ,659 & 112,270 & 58 & 000 & 1,155 \\
\hline
\end{tabular}

a. Predictors: (Constant), Ln.Hk

b. Dependent Variable: LN.Hp

Fenomena selanjutnya adalah sarang laba-laba (cobweb Phenomena) yaitu suplai dari berbagai komoditi pertanian bereaksi terhadap harga dengan beda kala (lag) satu satuan waktu, sebab keputusan tentang suplai memerlukan waktu untuk implementasinya (the gestation period). Perlu ada perbaikan dengan melakukan transformasi data yang menunjukkan adanya autokorelasi, jika persamaan regresi terjadi autokorelasi maka harus adanya perbaikan yaitu dengan menghitung $\rho=$ perkiraan $\rho$ dengan asumsi hanya terjadi autoregresif order pertama dan untuk mentransformasikan data asli, seperti halnya mencari selisih umum (generalized difference equation) (Gujarati, 2012). Transformasi perbedaan pertama yang disajikan tadi sangat popular dalam ekonometrika terapan karena mudah dilaksanakan. Karena $d$ sudah diketahui, gunakan teknik Theil Nagar untuk memperoleh perkiraan $\rho$ sebagai berikut:

$$
\begin{gathered}
\rho=1-\frac{d}{2} \\
\rho=1-\frac{1,155}{2} \\
\rho=0,423
\end{gathered}
$$

Setelah dilakukan perhitungan dengan rumus di atas dapat diperoleh nilai $\rho$ sebesar 0,423 . Setelah itu data sekunder yang sudah di Ln akan dilakukan transformasi data dengan mengunakan taksiran sebagai berikut:

(LnHp - $\rho$ LnHpt-1) dan (LnHk - $\rho$ LnHkt-1) (Gujarati, 2012).

Caranya adalah menggunakan nilai $\rho=0,423$ kali ini dengan variabel sebelumnya dari nilai saat ini. Nilai pertama dari harga produsen dan harga konsumen akan ditransformasikan sebagai berikut:

$$
\sqrt{ }(1-\rho 2) \operatorname{LnHp1} \text { dan } \sqrt{ }(1-\rho 2) \operatorname{LnHk1}
$$

Setelah dilakukan transformasi data maka data dapat dianalisis regresi kembali dan diperoleh nilai $d$ (Durbin-Watson) yang diantaranya nilai dl dan du dan output yang sudah ditransformasikan dapat dilihat pada Tabel 8 berikut : 
Tabel 8. Nilai Koefisien Regresi Transformasi Harga Produsen dan Konsumen Terung Ungu di Kabupaten Indramayu Tahun 2013-2017

\begin{tabular}{|c|c|c|c|c|c|c|c|c|}
\hline \multicolumn{9}{|c|}{ Coefficients $^{a}$} \\
\hline \multirow[t]{3}{*}{ Model } & \multirow{2}{*}{\multicolumn{2}{|c|}{$\begin{array}{l}\text { Unstandardized } \\
\text { Coefficients }\end{array}$}} & \multirow{3}{*}{$\begin{array}{c}\text { Standardized } \\
\text { Coefficients }\end{array}$} & \multirow{3}{*}{$\mathrm{T}$} & \multirow{3}{*}{$\begin{array}{c}\mathrm{R} \\
\text { Square } \\
\text { Change }\end{array}$} & \multirow{3}{*}{$\begin{array}{c}\mathrm{F} \\
\text { Change }\end{array}$} & \multirow{3}{*}{$\begin{array}{l}\text { Durbin- } \\
\text { Watson }\end{array}$} & \multirow{3}{*}{ Keterangan } \\
\hline & & & & & & & & \\
\hline & B & $\begin{array}{l}\text { Std. } \\
\text { Error }\end{array}$ & & & & & & \\
\hline \multirow[t]{2}{*}{ (Constant) } &,- 150 & ,194 & &,,- 774 & \multirow{2}{*}{,915 } & \multirow{2}{*}{627,045} & \multirow{2}{*}{2,264} & \multirow{2}{*}{$\begin{array}{l}\text { Tidak terjadi } \\
\text { autokorelasi }\end{array}$} \\
\hline & ,970 & ,039 & ,957 & 25,041 & & & & \\
\hline
\end{tabular}

a. Dependent Variable: h_prod

Keterangan :

$\mathrm{N}=60 ; \mathrm{K}=2 ; \mathrm{dl}=1,514 ; \mathrm{du}=1,651$ Critical Values for Durbin Watson Test: $5 \%$ Significant Level Berdasarkan hasil transformasi data di atas. Maka diperoleh nilai Durbin-Watson sebesar 2,264 dengan tingkat keyakinan 95\%. Uji regresi variabel independen dan jumlah pengamatan sebanyak 60, Tabel 8 memperlihatkan nilai $\mathrm{dl}=1,514 ; \mathrm{du}=1,652$. Apabila hipotesis adalah:

$\mathrm{H} 0: \rho=0$ (tidak ada autokorelasi positif)

H0 : $\rho \neq 0$ (ada autokorelasi positif)

Maka keputusan yang tepat adalah:

$\mathrm{d}<\mathrm{dl}$ : menolak H0

$\mathrm{d}>\mathrm{du}$ : tidak menolak $\mathrm{H} 0$

$\mathrm{dl} \leq \mathrm{d} \leq \mathrm{du}$ : pengujian tidak meyakinkan nilai $d$ yang didapat sebesar 2,264 sehingga menunjukkan bahwa tidak menolak H0 yaitu tidak terjadi autokorelasi positif.

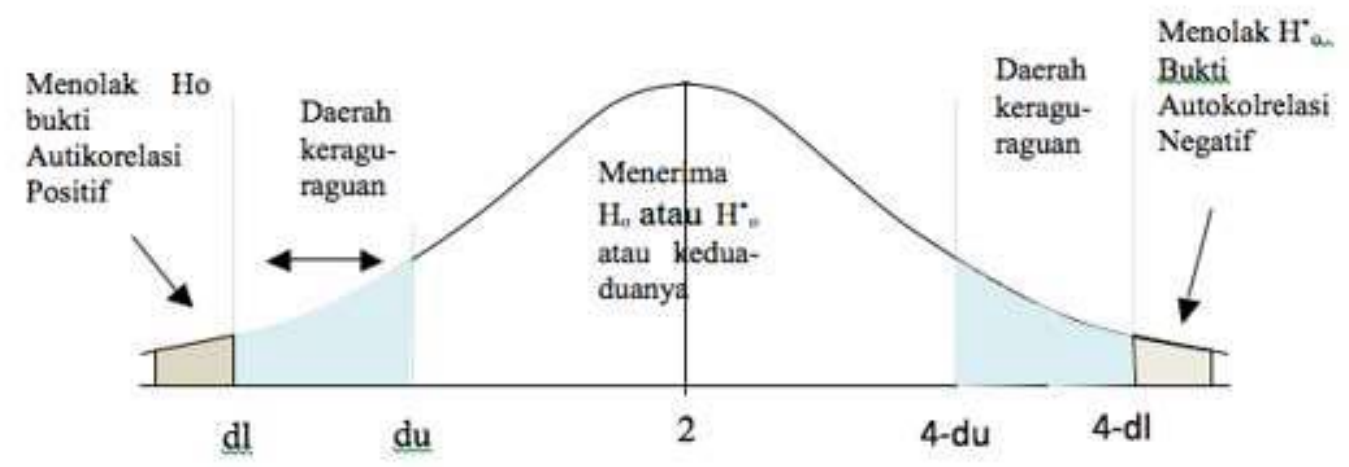

dl $: 1,514$ du $: 1.652 \quad \mathrm{dw}: 2.264$

Gambar 5. Hasil Posisi Koefisien D-W

\section{Heterokedastisitas}

Heterokedastisitas adalah asumsi dalam regresi dimana varietas dari residual tidak sama antar satu pengamatan dengan pengamatan yang lainnya (Gujarati,2012). Dasar pengambilan keputusan dalam uji heterokedastisitas dengan grafik Scatterplot: 
a. Jika terdapat pola tertentu pada grafik Scatterplot SPSS, seperti titik yang membentuk pola yang teratur (bergelombang, menyebar kemudian menyempit), maka terjadi heterokedastisitas.

b. Jika tidak terjadi pola yang jelas serta titik-titik menyebar. Maka tidak terjadi heterokedastisitas.

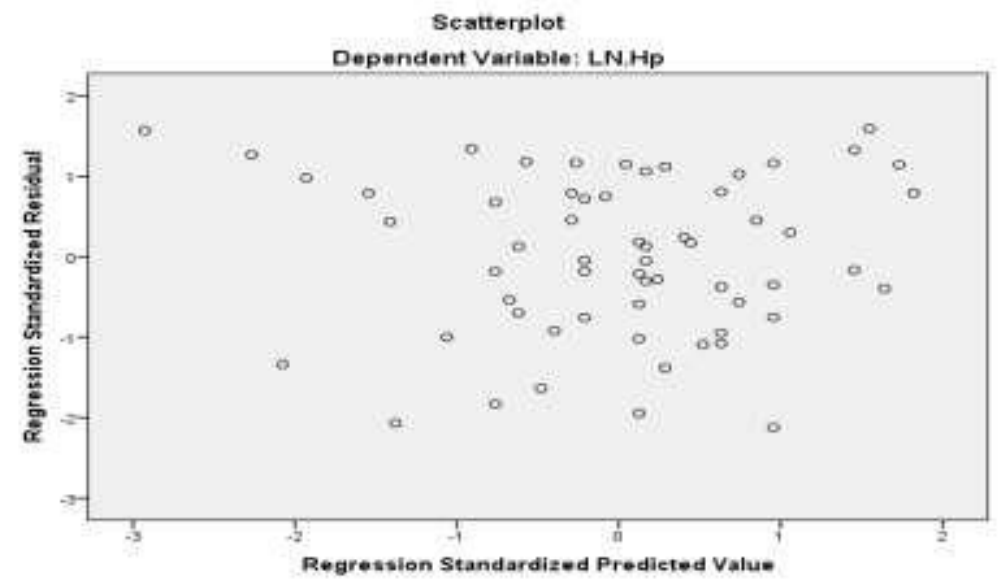

Gambar 6. Scatterplot Dependent Variable : Ln_Hp

Hasil output SPSS 23 pada gambar 6. Menunjukan membentuk pola menyebar maka hal ini dapat disimpulkan jika data tersebut tidak terjadi heterokedastisitas. Setelah suatu data tidak terjadi autokorelasi, multikorelasi, heterokedastisitas dan data berdistribusi normal. Maka dapat ditentukan data tersebut sudah dapat memenuhi asumsi klasik, dan data bersifat BLUE (Best Linier Unbias Estimasi).

\section{Efisiensi Pemasaran Terung Ungu}

Setelah dilakukan perhitungan tingkat efisiensi pemasaran terung ungu menggunakan analisis regresi kuadratik dengan data yang ditransformasikan ke dalam bentuk linier. Perhitungan ini menggunakan aplikasi SPSS 23. Setelah melakukan analisis maka diketahui nilai untuk elastisitas transmisi harga sebesar 0,792 maka Et $<1$ tetapi di dalam persamaan regresinya terjadi masalah autokorelasi. Transformasi data menggunakan teknik Theil Nagar dan diperoleh nilai elastisitas transmisi harga sebesar 0,970 maka nilai Et $<1$ yang berarti pemasaran terung ungu di Kabupaten Indramayu tidak efisien. Besarnya elastisitas transmisi terung ungu 0,970 artinya perubahan harga sebesar $1 \%$ di tingkat konsumen akan mengakibatkan perubahan harga sebesar 0,970\% di tingkat produsen.

\section{IV.KESIMPULAN}

\section{Kesimpulan}

Berdasarkan hasil penelitian maka dapat ditarik simpulan sebagai berikut:

1. Besarnya nilai elastisitas trasnsmisi harga sebesar 0,970 artinya Et kurang dari 1 yang berarti terjadi perubahan harga yaitu sebesar $1 \%$ menunjukkan persentase kenaikan harga di tingkat konsumen lebih rendah dibandingkan tingkat produsen, dan perubahan harga sebesar $1 \%$ di tingkat konsumen akan mengakibatkan perubahan harga di tingkat produsen sebesar $0,970 \%$.

2. Pemasaran terung ungu di Kabupaten Indramayu tidak efisien. 


\section{Saran}

Berdasarakan simpulan di atas maka dapat diperoleh saran sebagai berikut:

1. Perlu ada perhatian dan dukungan dari pemerintah untuk lebih memperhatikan pemasaran produk pertanian dengan mengupayakan tersedianya informasi pasar, sarana trasportasi yang memadai dan kebijakan pemerintah yang mendukung pembangunan pertanian agar pemasaran terung ungu efisien.

2. Perlu diupayakan pencapaian efisiensi pemasaran terung ungu dengan pembentukan kelembagaan seperti koperasi dan kelompok tani.

\section{Ucapan Terima Kasih}

Ucapan Terimaksih saya ucapkan kepada Fakultas Pertanian dan LPPM UNWIR yang telah membantu dalam penelitian ini sehingga penelitian dapat dijalankan.

\section{DAFTAR PUSTAKA}

Algifari. 2000. Analisis regresi, teori kasus dan solusi. Yogyakarta(ID): BPFE UGM.

Andriani N. N. 2015. Efisiensi Pemasaran Kacang Panjang (Vigna sinensis, L.) di Kabupaten Indramayu. Skripsi. Indramayu. Program Studi Agribisnis, Fakultas Pertanian, Unversitas Wiralodra.

Arief, A. 1990. Hortikultura. Yogyakarta(ID): Andi Offset.

Asmarantaka, R . A. 2009. Pemasaran Produk Pertanian. Bunga rampai Agribisnis Seri Pemasaran.

Assauri, S. 2004. Manajemen Pemasaran: Dasar, Konsep, dan Strategi, Cetakan 7. Jakarta(ID): Pt. Raja Grafindo Persada.

Azzaino, Z. 1982. Pengantar Tataniaga Pertanian. Departemen Ilmu-Ilmu Sosial Ekonomi. Fakultas Pertanian. Institut Pertanian Bogor. Bogor.

Badan Pusat Statistika Jawa Barat. 2014. Jawa Barat Dalam Angka. Jawa Barat Badan Pusat Statistika Jawa Barat. 2015. Jawa Barat Dalam Angka. Jawa Barat.

Badan Pusat Statistika Jawa Barat. 2016. Jawa Barat Dalam Angka. Jawa Barat.

Badan Pusat Statistika Jawa Barat. 2017. Jawa Barat Dalam Angka. Jawa Barat.

Badan Pusat Statistika Jawa Barat. 2018. Jawa Barat Dalam Angka. Jawa Barat.

Badan Pusat Statistika Kabupaten Indramayu. 2018. Indramayu Dalam Angka. Indramayu.

Bangun, A. 2010. Analisis Pemasaran Udang Windu. Skripsi. Departemen Agribisnis, Fakultas Ekonomi dan Manajemen, IPB. Bogor.

Denziana, Angrita dkk. 2014. Corporate Financial Performance Effects Of Macro Economic Factors Against Stock Return. Jurnal Akutansi \& Keuangan, Universitas Bandar Lampung [internet]. [2019 Agustus 14]: Lampung. 
Downey, W. D. dan Steven. P. E. 1992. Manajemen Agribisnis (edisi kedua) (penerjemah: Alfonsus Sirait). Jakarta(ID): Erlangga.

Firdaus, Muhammad. 2008. Manajemen Agribisnis. Jakarta(ID): Bumi Aksar.

Firmanto, B. 2011. Sukses Bertanam Terung Secara Organik. Bandung(ID): Angkasa.

Gitosudarmo, I. 1997. Manajemen Pemasaran. Yogyakarta(ID): BPFE.

Gujarati, D. N. 2012. Dasar-Dasar Ekonometrika. Alih Bahasa Mangunsong. Jakarta(ID): Salemba Empat.

Gulo, W. 2000. Metodologi Penelitian. Jakarta(ID): Grassindo.

Hidayat, Anwar. 2017. Pengertian dan Penjelasan Uji Autokorelasi Durbin Watson [internet]. [2019 Agustus 04] https://www.statisyikian.com/2017/01/uji-autokorelasi-durbin-watson-spss.html

Kartasopoetra, AG. 1987. Teknologi Penyuluhan Pertanian. Jakarta(ID): PT. Bumi Aksara.

Kirckpatrick, C.D. dan Dahlquist J.R. 2011. Technical Analysis. The Complete Resource for Financial Market Technicians. Pearson Education, Inc. New Jersey. USA.

Limbong, W.H. dan P. Sitorus. 1987. Pengantar Tataniaga Ekonomi. Fakultas Pertanian, IPB.

Mubyarto. 1989. Pengantar Ekonomi Pertanian. Jakarta(ID): LP3ES.

Mubyarto. 1995. Pengantar Ekonomi Pertanian edisi ketiga. Jakarta(ID): LP3ES.

Nazir, M. 2005. Metode Penelitian. Jakarta(ID): Ghalia Indonesia.

Nazir, M. 2011. Metode Penelitian. Bogor(ID): PT Ghalia Indonesia.

Nugroho. H dan D. Novalinda, 2007. Usaha Sayuran Sehat Dataran Rendah. Jambi: Balai Pengkajian Teknologi Pertanian.

Pracoyo, Tri dan Antyo. P. 2006. Aspek Dasar Ekonomi Mikro. Jakarta(ID): Grasindo.

Rahayuningsih. 2009. Analisis Keterpaduan Pasar Tomat (Lycopersicum esculentum) antara Tawangmangu Kabupaten Karanganyar dengan Pasar Legi Surakarta. Skripsi. Program Studi Sosial Ekonomi, Pertanian/Agribisnis. Fakultas Pertanian. Universitas Sebelas Maret Surakarta. Surakarta.

Rahim dan D. R. D. Hastuti. 2005. Sistem Manajemen Agribisnis. State University of Makasar Press. Makasar.

Rukmana, R. 2002. Bertanam terung. Jogyakarta(ID): Kanasius.

Santoso, T.I. 2014. Efisiensi Pemasaran Beberapa Komoditas Sayuran penting Utama di Kabupaten Indramayu, Jurnal. Program Studi Agribisnis, Fakultas Pertanian, Universitas Wiralodra Indramayu.

Soekartawi. 1999. Agribisnis Teori dan Aplikasinya. Jakarta(ID): Raja Gravindo Prasindo Persada 
Stanton, W. J. 2004. Prinsip Pemasaran. Edisi Ketujuh Jilid kesatu. Jakarta(ID): Erlangga.

Sudiyono A. 2004. Pemasaran Pertanian. Malang. Malang(ID): Universitas Muhammahdiyah Malang.

Sudiyono, A, 2000. Pemasaran Pertanian. Malang(ID):Universitas Muhammadiyah Malang.

Sudiyono. 2014. Metode Penelitian Pendidikan Pendekatan Kuantitatif, Kualitatif dan R\&D. Jakarta(ID): Alfabeta.

Sunarjono. H. 2013. Bertanam 30 Jenis Sayuran. Jakarta(ID): Penebar Swadaya.

Widyaningsih, H. 2018. Efisiensi Pemasaran Pepaya (Carica papaya, L.) di Kabupaten Indramayu. Skripsi. Program Studi Agribisnis, Fakultas Pertanian, Unversitas Wiralodra

William J Stanto. 1985. Prinsip Pemasaran. Edisi ke-7. Jakarta(ID): Erlangga.

Wiratha, I. M. 2006. Metodologi Penelitian Sosial Ekonomi. Yogyakarta(ID): Andi Offset. 